\title{
A Shift in U.S. Foreign Policy under the Nixon Administration and European Political Cooperation: A Historical Analysis
}

\author{
Thi Thuy Hang Nguyen \\ School of Global, Urban and Social Studies, \\ RMIT University \\ 411 Swanston Street, \\ Melbourne VIC 3000, Australia \\ E-mail: s3374642@student.rmit.edu.au
}

Abstract: With a historical approach, this paper examines the Nixon administration's policy and stance towards the European Political Cooperation (the EPC). In December 1969, at The Hague Summit the leaders of the European Community expressed their determination for deepening European integration. The final communiqué of The Hague Summit stressed the European Community's desire to achieve the EPC and to parallel the European Community's increasing economic strength with a role to play in the world affairs. With this in mind, the paper will examine the impacts that Nixon administration's attempts to rebalance U.S. foreign relations reflected in the opening to China and the détente with the Soviet Union had on the European political integration. Then, it will be argued that the Nixon administration's shifting of foreign policy priorities can be seen as one of the driving forces of the EPC. The paper puts forth that a European Community, whose weight was increased first by its economic integration and then by its political cooperation, was seen by the Nixon administration as a challenge to the United States. It is concluded that after a long time of consistently supporting European integration as a means to secure peace and prosperity in Europe, the United States under the Nixon administration had to reconsider its foreign relations and rebalance its focus on the global chessboard. This rebalancing certainly impacted the EPC in particular and the European integration process in general.

Keywords: European Community, European integration, European Political Cooperation (EPC), Nixon administration 


\section{Introduction}

This paper aims to offer a historical analysis of how the Nixon administration's foreign policy shift from confrontation to negotiation with the Soviet Union and China had constituted a stimulus for the European Community's leaders to deepen the European integration project through the launch of European Political Cooperation (EPC). It also examines the Nixon administration's stance towards EPC and the Nixon administration's redefinition of the U.S. approach to European integration. When the Nixon administration arrived at the White House in 1969, the world was entering a new age which was characterized by relaxation in international relations. The Nixon administration reconsidered the U.S. foreign policy priorities, which were reflected in President Nixon's policy to open to China and reduce tensions with the Soviet Union. The U.S. search for diplomatic normalization with the Chinese and détente with the Soviets was seen as one of the impulses for the European Community's leaders to develop their plan for political cooperation. The launch of EPC somehow led to certain changes in the U.S. attitudes towards European integration.

Therefore, this paper will begin with a comprehensive analysis of the Nixon administration's diplomatic activities to open to China and reduce tensions with the Soviet Union. Then, it will shed light on how the Nixon administration's policy towards China and the Soviet Union drove the European political cooperation. The Davignon Report, approved by the Foreign Ministers of the Six in Luxembourg in October 1970, was the starting point of EPC. The Davignon Report intensified a growing sense that a common European political and foreign policy was taking shape and it outlined the institutional structure for EPC to be realized. Despite showing its enthusiasm to the European endorsement of the Davignon Report, the Nixon administration knew from the outset that EPC might become a challenge to the United States as it used the collective power of the Six to raise its concern about great issues in world affairs. It will be concluded that after a long time of consistently supporting European integration as a means to secure peace and prosperity in Europe, the United States needed to rebalance its focus on the global chessboard. With a realist view of the world politics, President Nixon downgraded European integration process in his foreign policy agenda. 


\section{The Nixon administration: shifting U.S. foreign policy priorities}

In his article entitled 'Asia after Vietnam', published in Foreign Affairs in October 1967, Richard Nixon once acknowledged that "Asia had been undergoing a profound, an exciting and on balance an extraordinarily promising transformation" (Nixon, 1967). The Asian transformation was characterized by the emergence of Asian regionalism, the development of the Asian economies and the disaffection with old political ideas. With this transformation, Asia would become strategically important to U.S. interests and global leadership. Richard Nixon suggested focusing U.S. foreign policy on Asia to build a Pacific community in that part of the world. This implied a change in the priorities of U.S. foreign policy, shifting the focus from the West to the East:

the United States, with its coast reaching in an arc from Mexico to the Bering Straits, is one anchor of a vast Pacific community. Both our interests and our ideals propel us westward across the Pacific, not as conquerors but as partners. (Nixon, 1967)

In his inaugural address on January 20, 1969, President Richard Nixon sent an important message: the United States was prepared to embark on "an era of negotiation" with the Communist world. This declaration signaled the change of emphasis in the U.S. foreign policy: The Nixon administration sought to improve relations between the United States and its two Communist opponents - China and the Soviet Union. While the United States saw all Communist nations as a united enemy, the relationship these between two Communist giants showed signs of strain. As early as 1969, China and the Soviet Union were deeply divided by direct confrontations. Namely, the border dispute along the Ussuri River resulted in heavy casualties. The defense pacts offered by the Soviet Union to the Southeast Asia's countries were seen by Beijing a hostile policy toward China. As for China, the direct confrontations with the Soviet Union led Zhou Enlai and Mao Zedong to begin reconsidering China's geopolitical strategy. They knew that Chinese forces could not match the Soviet Union's. The Soviet threat made China see improved relations with the United States as the best strategy to protect China's security. The Nixon administration realized how the Sino-Soviet split might be played to the United States' advantage. President Nixon saw it as a chance for Washington to play Moscow and Beijing against each other to improve relations with both countries. The Nixon administration decided to exploit this widening rift to U.S. advantage. If Washington reconciled with Beijing, Moscow would have no choice but to cooperate with Washington, or risk becoming isolated. 
In order to fulfill their promise to shift the Cold War landscape from an "era of confrontation" to an "era of negotiations", President Richard Nixon and Henry Kissinger set up a back channel for direct communication with the Soviet Union and later with China as the President believed that this rapprochement "should be done privately and should under no circumstances get into the public prints from this direction" (FRUS, 1969-1976a). This new channel also ignored the traditional diplomacy which was regularly carried out through the foreign services and overseas embassies.

\subsection{Opening to China}

Though there was an evident rivalry between the Soviet Union and China after 1960, both President Kennedy and President Johnson held the previous policy stance and attitudes toward China. They still believed that the SinoSoviet relationship was built and developed on essentials and was thus hostile to the United States and the capitalist world. Washington's anti-China policy was mainly expressed in their non-recognition and trade restrictions. However, the Nixon administration considered it was essential to bring China into the diplomatic constellation as Richard Nixon (1967) had noted: "We simply cannot afford to leave China outside the family of nations". He saw the need to engage with China as this nation was playing an important role in Asian chess board: "any American policy toward Asia must come urgently to grips with the reality of China" (Nixon, 1967). In his memoirs, Nixon wrote: "I was fully aware of the profound ideological and political differences between our countries [...] But I believed also that in this era we could not afford to be cut off from a quarter of the world's population. We had an obligation to try to establish contact [...] and perhaps move on to greater understanding." (Nixon, 1978, p. 343)

President Nixon directed that a study had to be prepared on U.S. policy towards China (FRUS, 1969-1976c). The Nixon administration soon sent China signals about improving Sino-U.S. relations (Paterson et al., 1991). The Nixon administration began its plan to approach China by allowing U.S. citizens to buy Chinese commodities without special permission, validating passports after 1970 for travelling in China, and approving, after April 1970, the export of certain nonstrategic U.S. goods to China (Paterson et al., 1991). One important signal from President Nixon to improve the relationship with China was his usage of Beijing's official title, the People's Republic of China during his stop in Romania in October 1970.

The Nixon administration's new attitudes and perceptions were positively responded by Beijing. China welcomed Washington's move towards the 
normalization of U.S.-Sino relationship and expressed its interest in face-to-face discussions. It was noted that China had employed what was known as 'pingpong diplomacy' in a graceful manner. In April 1971, the Chinese ping-pong team invited the U.S. team competing for the world's championship in Nagoya, Japan to visit China. In his address to the U.S. ping-pong team, Chinese Prime Minister, Zhou Enlai said: "[w]ith your acceptance of our invitation, you have opened a new page in the relations of the Chinese and American people. I am confident that this beginning again of our friendship will certainly meet with the majority support of our two peoples." (Roderick, 1971) After a pause he then asked the Americans: "Don't you agree with me?" and the Americans showed their agreement with a big applause (Roderick, 1971).

Then Prime Minister Zhou Enlai informed Washington that "the Chinese Government reaffirms its willingness to receive publicly in Beijing a special envoy of the President of the U.S. (for instance, Mr. Kissinger) or the U.S. Secretary of State or even the President of the United States himself for a direct meeting and discussions" (Isaacson, 1992, p. 339). On 15 July 1971, President Nixon announced to the U.S. public about Kissinger and Zhou Enlai private talks in Beijing before U.S. ping-pong team came to China. Also, Prime Minister Zhou Enlai had invited President Nixon to visit China and his invitation had been accepted. Both U.S. and Chinese leaders expressed the desire to clear away mutual misperceptions and to define the real nature of some of the more outstanding issues and problems impeding improved Sino-American relations. Actually, the United States made significant progress in the rapprochement with China during the Nixon administration.

On February 21, 1972, President Nixon arrived in Beijing and paid a sevenday historic visit to China. This was seen as the most obvious manifestation of the Nixon administration's opening to China. President Nixon publicly shook hands with Mao Zedong and was toasted by Zhou Enlai in the Great Hall of the People. Nixon's trip to China ended with a Joint Communiqué in Shanghai (also referred to as the Shanghai Communiqué) on 28 February 1972, in which the leaders of the United States and China agreed to temporarily put aside the major question hindering the normalization of relations, the political status of Taiwan, and opened trade and other contacts.

Opening to China would, Washington hoped, be a prerequisite to ease the strained relations with the Soviet Union. The prospect of improved relations between the United States and China caused concern in Moscow, thus motivated the Kremlin to be "more conciliatory on such prominent and substantial issues as arms control of offensive and defensive strategic missiles" (Spanier, 1980, 
p. 178). For the United States, the opening to China was a strategy to exploit the rivalry between Beijing and the Moscow. The implied message to the latter was that Soviet obstinacy would compel the United States to align itself more closely with China. To the Soviet Union, such alignment would be a nightmare. After the historic visit to China in February 1972, President Nixon arrived in Moscow on May 22, 1972 and met with the leading Soviet officials.

\subsection{Relaxing with the Soviet Union}

The United States' willingness to follow a policy of easing of Cold War tensions was met with approval by Leonid Brezhnev, General Secretary of the Soviet Communist Party. This was officially shown in the note from the Soviet leadership to President Nixon:

On our part, we believe, as before, that both sides should have to work for better Soviet-American relations...Relaxation of international tensions and improvement of relations between the USSR and the U.S. would be, we are confident, in the interests of our peoples and other peoples of the world. Such is our firm line and we are consistently following it (FRUS, 1969-1976d).

At the Moscow summit in March 1972, Nixon and Brezhnev reached an agreement on "mutually acceptable" limits in their countries' nuclear capabilities which had been negotiated since November 17, 1969. This ultimately resulted in the signing of the SALT I agreement (Strategic Arms Limitation Talks) in May 1972 (Spanier, 1980, p. 183). Noticeably, negotiations on SALT II also began in 1972. More importantly, that Leonid Brezhnev paid a visit to the United States for the Washington summit in June 1973 marked the highest point in the era of détente between the United States and the Soviet Union. During two days of the Washington summit they inked four pacts for cooperation in oceanography, transportation, cultural exchange, and agriculture (Graebner, Burns \& Siracusa, 2010 , p. 353). After that they had a discussion on nuclear disarmament and troop reductions in Central Europe and they considered their subsequent pact to avoid nuclear war as the major success of the Washington summit. The issue of a 20-page communique calling for further relaxation in the relations between the United States and the Soviet Union was welcomed by the peoples of both countries. According to Phil Williams (1987, p. 577), Nixon considered détente as a "means of disciplining Soviet power" to contain the wild Soviets in the international arena. As for the Soviet Union, Kremlin considered the main benefit and their aim of détente as "offering new opportunities for exercising power" to avoid an all-out war or nuclear war (Williams, 1987, p. 577). 
In spite of such achievements, the Washington summit in 1973 still showed that both Nixon and Brezhnev knew the risks and costs of their long-lasting rivalry and the advantages of stabilization of Washington-Moscow relationship. However, the Soviet leaders remained stuck in their ideological differences with the West and President Nixon was unable to convince some in his administration of the necessity to be friendly with the Soviet Union as these people held that Moscow presented an immediate threat to the United States.

The relaxation of tensions with the Soviet Union was one of the focuses in President Nixon's foreign policy's goal. His administration had reasons for wanting to improve its relations with China and the Soviet Union. First, the Nixon administration desired to extricate the United States from the Vietnam conflict without suffering a humiliating defeat. This, President Nixon believed, could be obtained by isolating North Vietnam from its two main sources of supply and support, the Soviet Union and China. Another reason lay in Nixon's assumption that détente with the Soviet Union would help to conclude a SALT agreement that would limit the size of the Soviet nuclear arsenal, and thus restrain the Soviet strategic buildup. Also, the new approach to Moscow and Beijing brought the United States economic benefits. U.S. foreign trade was in need of a boost to eliminate a billion-dollar deficit in the balance of payments, détente could help the United States to access expanded markets. For instance, U.S. corporations like Pepsi-Cola and Chase Manhattan Bank began operations in the Soviet Union and U.S. businesses rushed to Asia in a revival of the great China market dream.

Shifting its foreign policy priorities to Asia reflected the Nixon administration's efforts to pursue its interests with Moscow while trying to improve its relations with Beijing. That the United States was dancing with both the Soviet Union and China reflected the multi-polar reality and U.S. adjustment to its relative decline. Even though everyone had no doubt that the United States still retained considerable power even at its nadir in the early 1970s, the trend of relaxing in the United States' foreign policies towards the two Communist nation-states was the result of its relative decline. Nixon and Kissinger had no desire to place much emphasis on the friendship with Western Europe as the previous administrations had done. These U.S. leaders looked to the East and supposed that China and the Soviet Union would have a significant role in helping the United States to cope with economic slowdown because they all had large developing markets. More importantly, the United States was seeking to escape the Vietnam War which was too costly to the United States. The relationship with China and the Soviet Union, which had important influence on the Northern Vietnam would somewhat help the United States to solve the problem of Vietnam War. Building relations 
with the Communists became a milestone in the Nixon administration's foreign policy. This shifting of foreign policy priorities led to the fact that U.S. support for European integration was not in high profile in the Nixon administration as it had been previously. In other words, the opening to China and the détente with the Soviet Union contributed to the reshaping of U.S. policy to the European unity.

\section{The European Community: planning for European Political Cooperation (EPC)}

By late 1969, the European Community's leaders remained that the relations with the United States were crucial to the peace and prosperity of Western Europe. They knew the significance of the United States in the political, economic and security fields and especially the interdependence of the United States and Western European economies. Yet, they realized that the United States facing relative decline was reexamining its foreign policy. After a long time of investing its time and energy in Western Europe, the United States under the Nixon administration saw the need to rebalance its foreign policy and reallocating its resources to the East. For example, the Nixon Doctrine set out by President Nixon on the $25^{\text {th }}$ of July in 1969 emphasized that the United States would make new diplomatic efforts to open negotiations and to clear away obstacles to negotiations with the Communist states, even if it was at expense of U.S. close ally (Kolodziej, 1976, p. 134). That the Nixon administration sought to improve relations with both China and the Soviet Union signaled the European Community's leaders that there would be challenges for them. In the context of reduced tensions in international relations, particularly between the United States and the Communist world, the European Community might not have a favorable position in the Nixon administration's foreign policy agenda. The European Community's leaders realized that it was time for the Six to unite politically to face potential challenges that the Nixon administration's foreign policy shift from the age of confrontation to the age of negotiation might pose to their Community. In other words, the shift in the Nixon administration's foreign policy towards the Soviet Union and China became a stimulus for the European Community's leaders to think of deepening the European integration project. Western Europe recognized the importance of political cooperation in the changing world order.

This realization became the European Community's leaders' argument in their efforts to develop a plan for EPC. The need for the Europeans to speak with one 
voice in its relations with the United States constituted the major reasons for deepening European integration in the area of political and foreign affairs. Like the Six's desire to build a European monetary union, their efforts to develop political and foreign policy cooperation aimed at building an equal and dependence-free relationship with the United States. The European Community's leaders believed that European political and foreign policy cooperation helped to complete the European integration. Their ideas of increasing European integration in the political and foreign policy reflected Western European endeavor to become a player in the international affairs and illustrated its increasing assertiveness in the Atlantic alliance.

The concept of European Political Cooperation (EPC) had been discussed since the early 1960s but had not been seriously considered and carried out because of the differences of opinion in this area between General de Gaulle and his partners. Georges Pompidou, de Gaulle's successor as French president in April 1969 held the key to the European Community's progress in political cooperation after the General's designation. The new President of France was in favor of Gaullism but was not subservient to de Gaulle's European Community policies. He tried to balance Gaullist hostile stance and policy towards political integration on the one hand, with increasing resentment in the European Community against French obdurateness on the other hand (Dinan, 2010, p. 42). The European Community's enlargement posed an obvious challenge. For de Gaulle and the strong advocates of Gaullism, the veto of the United Kingdom's applications in 1961 and 1967 had become sacrosanct. For an increasing portion of the French people and France's five partners, however, revoking the veto was the best way by which France would possibly sustain its influence in the European Community (Dinan, 2010, p. 42). Apprehensive of this reality, President Pompidou decided to lift France's political veto on the admission of the United Kingdom and embrace the idea of political cooperation.

In the post-Gaullist period and in facing the possible impacts of the Nixon administration's foreign policy shift, the concept of political cooperation received unanimous acceptance among the Six. In December 1969, four months after the declaration of the Nixon Doctrine, the heads of the Six convened at The Hague Summit and expressed their determination for an ever closer union. President Pompidou's catchphrase "completion, deepening, enlargement" was enthusiastically endorsed by the European Community's leaders. In the final communiqué of The Hague Summit, it was highlighted that the European Community attempted to achieve EPC and endeavored to parallel the European Community's economic increasing strength with a role to play in the world's great political issues. The heads of the Six instructed "the Ministers of Foreign 
Affairs to study the best way of achieving progress in the matter of political unification, within the context of enlargement" (The Hague Summit Declaration, 1969). They expected the Ministers' report would be completed before the end of July 1970.

The Belgian Political Director, Vicomte Davignon was tasked by the six foreign ministers in the early 1970 with preparing a report on which a new system of foreign policy cooperation might be formed. Davignon and his counterparts from the other five foreign ministries could not manage to produce the report by the end of July 1970. The report was finally completed and presented at the Luxembourg Conference of Foreign Ministers of the six European Community countries, in Luxembourg on 27 October 1970. It was endorsed by the foreign ministers and known as the 'Davignon Report'.

The spirit of the Davignon Report could be seen as one of the Six's responses to the age of negotiations opened by the Nixon administration. As for Western Europe, they wanted to see the slowdown in the arms race between the United States and Soviet Union, and the improved relations between the United States and China. However, they concerned about their political and strategic interests which could be jeopardized when President Nixon "attached major importance to the improvement of relations" (Dobrynin, 1995, p. 198). To make sure that the European Community's interests at home and abroad were secure and safe, the European Community's leader recognized that they needed to gradually develop an appropriate method of, and instruments for, joint political action:

The present development of the European Communities requires Member States to intensify their political co-operation and provide in an initial phase the mechanism for harmonising their views regarding international affairs. Thus, the Ministers felt that efforts ought first to concentrate specifically on the coordination of foreign policies in order to show the whole world that Europe has a political mission. (The Davignon Report, 1970)

The launch of EPC aimed to prepare the European Community to effectively act on the world stage: "Europe must prepare itself to carry out the responsibilities which, because of its greater cohesion and its growing role, it has the duty and necessity to assume in the world" (The Davignon Report, 1970). The leaders of the Six expressed their wish to cooperate in developing a political approach for Europe that "corresponds to its tradition and its mission" (The Davignon Report, 1970). This mission included preventing armed conflicts in the continent, promoting democracy, freedom and market economy. Broadly speaking, in Europe the European Community's leaders wanted to see the relaxation in the 
relations between East Europe and West Europe, in Asia they desired to trade and do business with the Chinese.

The Davignon Committee, established after the approval of the Heads of State and Government of the Member States of the European Community, was in charge of crafting a European common political stance in global affairs. This Committee had been successful in raising Western European unified position on security discussions as reflected in May 1970 NATO's Rome Communiqué:

Allied Governments would continue and intensify their contacts, discussions or negotiations through all appropriate channels, bilateral or multilateral, and that they remained receptive to signs of willingness on the part of the Soviet Union and other Eastern European countries to engage in such discussions. Progress, they said, in these discussions and negotiations would help to ensure the success of any eventual conference, in which of course, the North American members of the Alliance would participate, to discuss and negotiate substantial problems of cooperation and security in Europe. (NATO, 1970)

The Rome Communiqué was evidence that with the Davignon Committee, the Six managed to align their policy stance on European security which was prerequisite for the success of the European integration project. In addition, the Six's Davignon Committee was able to convince the NATO members to include the ultimate goal of the European integration process in the NATO's Rome Communiqué: It was in favor of "the development of international relations with a view to contributing to the freer movement of people, ideas, and information, and to developing cooperation in the cultural, economic, technical, and scientific fields as well as in the field of human environment" (NATO, 1970).

Having created an institutional basis for adopting a unified policy stance, the Six was able to insist on multilateral negotiations with Washington and showed their political assertiveness in world affairs. This of course made the Nixon administration frustrated. President Nixon would never want to see a European Community, whose weight was increased by first its economic integration and then its political cooperation, to modify Washington's foreign policy and security agenda on European terms and conditions. For the Nixon administration, the increasing reaffirmation of the Six was unacceptable and Kissinger vowed to "kill the Davignon Committee" (Kissinger, 1974). 


\section{The Nixon administration's dilemma: shifting and balancing}

Having focused on the opening to China and the détente with the Soviet Union, and having seen the Six's attempts to deepen their integration project through EPC, President Nixon and his administration recognized that Washington's policy to reduce tensions in international relations had pushed the European Community to be closer. President Nixon was of understanding that the continuity of cooperation among the member states of European Community was necessary as underlined by John Foster Dulles:

We are engaged in a global struggle, as in World War II. We cannot expect success if we so scatter our efforts that we are ineffectual everywhere. We have made the recovery of Western Europe our major initial goal, but it must not be our sole concern. As quickly as possible, we need to turn elsewhere. To do that safely requires increased unity in Europe. (Dulles, 1950, p. 223)

As an experienced politician and leader, President Nixon knew that before his administration could turn elsewhere, he had to ensure European unity would not be detrimental to his foreign policy goals. Especially, by the late 1960s, according to U.S. National Intelligence Estimate: "Western Europe today is more prosperous, more democratic, and more secure than at any time in modern history." (FRUS, 1969-1972b)

As the European Community's economic strength was increased, its leaders had endeavored to raise its voice in international affairs. The dilemma facing the Nixon administration was how to realize its policy of reducing tensions with the Communist world while preventing any cartel move in Western Europe which might adversely affect Washington's strategic interests. This led to the adaptation in U.S. policy towards European integration which could be described as "a form of wary containment" (Smith, 2012, p. 223). The European Community's plan for political cooperation constituted a source of worry for the Nixon administration. It is noted that European declaration on political cooperation basically did not result in substantive change in U.S. policy to reduce tensions with the Soviet Union and normalize relations with China. However, the developments of détente with the Soviets and opening to China on the Nixon administration side and the dynamics of political cooperation on the European Community revealed that the United States needed Western Europe as much as the Western Europe needed them. The European integration process was mainly driven by the Europeans as response to their alleged challenges. 
Also, it was apparent that the course of European integration to certain extent had been and would be affected by the Nixon administration's policy changes as the U.S. National Intelligence underlined:

Although the policies of the European states and the pace and extent of integration will be determined by the Europeans themselves, they will also be influenced by the attitudes and policies of the U.S. For the past 25 years, the U.S. has been the single most important political, economic, and military factor in Western Europe. In these circumstances, periodic tension and strain between the U.S. and various nations over specific issues or general concepts is both natural and unavoidable. The U.S. has been the guarantor of West European security, the principal sponsor of Germany's political rehabilitation, the major source of technological progress, and the mainstay of economic and financial stability. As such, it has been the target of criticism by some but of courtship by all. (FRUS, 1969-1972b)

To sum up, the Nixon administration's shift from the age of confrontation to the age of negotiation had repainted the picture of the international environment. President Nixon and his team had placed the détente with the Soviet Union and the rapprochement with China as the first priorities on their foreign policy agenda. This implied that Western European integration was downplayed in the Nixon presidential years. U.S. policy makers knew that this shift in international relations was crucial to protect and promote their national interests. Reducing tensions between the West and the Communist World was somehow welcomed by the European Community's leaders as they saw opportunities to avoid all-out war or nuclear war between the two great world powers, whose main battlefields would be in Europe. Also, the European Community's leaders, who had been pursuing to enhance Western Community's material strength, wanted to penetrate into China's massive market. Actually, there was a linkage between the Nixon administration's policy to the Soviet Union and China and the European integration project. Nixon administration's policy to the Soviet Union and China was one of the driving forces behind the European Community's attempt to establish EPC as Mike Smith observed that "the Nixon-Kissinger foreign policy conducted between the late 1960s and the mid-1970s played a crucial catalytic role" (Smith, 2012, p. 222). The plan for EPC, in the Nixon administration's view, might be Western European efforts to challenge the United States' leadership in the free world. Henceforth, the Nixon administration's policy towards European integration in general was not favorable as it used to be in the previous administrations. President Nixon and his administration saw "the European integration as much more of a problem than a solution" (Smith, 2012, p. 222). 


\section{The Nixon administration: redefining U.S. approach to European integration}

During his trip to European capitals in February 1969, President Nixon declared that his administration would renew U.S. relations with the Europeans. This was seen as a signal of bringing the relationship between the two sides of the Atlantic Ocean to a new height. Yet, President Nixon's promise was not realized as his administration sought to implement the diplomacy of great power politics with the Soviet Union and China.

The new international environment that the Nixon administration opened up was characterized with this shift in U.S. foreign policy from confrontation to negotiation with its enemies. The European Community also embarked on its long road to political cooperation partly driven by President Nixon's new policy on the Communist World. The European Community's leaders soon realized that their hope for having a central place in the Nixon administration's foreign policy was illusionary. President Nixon did not have any intention to make major diplomatic efforts to strengthen the partnership with Western Europe. He did not want the United States to involve in a more interdependent Atlantic alliance. His core diplomatic goals were to regain for Washington its freedom to act and freedom to pursue its strategic interests. The Nixon administration wanted the United States to be seen as an ordinary nation. Implicitly, the Nixon administration sought to free the United States from unnecessary responsibilities to pursue great power diplomacy, and to "leave the internal evolution of a United Europe to the Europeans" (Thornton, 2001, p. xviii).

In addition, under the Nixon administration, the United States exercised its hegemonic power with Western Europe and ignored negotiations as a diplomatic means of settling conflicts. This naturally led to more assertiveness and reaffirmation from the European Community in its relations with the United States. The main step that illustrated the European Community's assertiveness and reaffirmation was the meeting of the European Community heads of states in December 1969 in The Hague, the Netherlands where the plan for political cooperation was approved. This was a realistic move to deepen European integration. The move towards European political cooperation reflected that the European Community wanted to have a common stance on great political issues in the world affairs. The European Community desired to be a giant in not only economic but also political fields. This highlighted the European Community's reaffirmation and assertiveness in its relations with the United States. 
In the Nixon administration's view, the United States' policy of placing much focus on building a partnership with Western Europe since the end of World War II was inappropriate in a new era. In other words, Western Europe and its integration process were no longer seen as a cornerstone of the Nixon administration's foreign policy. Seeing Europe growing fast materially the Nixon administration had reasons to worry. The European Community was about to challenge the United States in the economic front while the United States was preoccupied with great power politics. Instead of pursuing policy in favor of U.S. economic prosperity, the European Community tended, in Nixon's view, to become a protectionist bloc that might not only include the Six but also African and Asian nations (Kissinger, 1979, p. 192). The Nixon administration recognized that the United States had been invested much material and political resources into Western Europe and underestimated the importance of the Soviet Union and China in their comprehensive foreign policy. Despite receiving many privileges from the United States, the European Community had not been a reliable partner to Washington. Put simply, the Nixon administration knew that it was time for the United States to re-examine its foreign policy and rebalance its international relations. In parallel with its view of shifting its focus from Europe to Asia was its redefining of U.S. approach to European integration. Instead of providing substantial economic and political support for European integration as the previous administrations had done, the Nixon administration saw it as the internal affairs of the European Community.

\section{Conclusion}

During the Nixon administration, the United States saw the need to shift its foreign policy priorities from the West to the East. It started negotiations with the two Communist giants and this led to changes in the U.S. policy towards the Soviet Union and China. Instead of claiming these nations to be U.S. enemies, the Nixon administration shook hands with the leaders of these nations and invited cooperation for peace from them: "We have always made it clear that we have no permanent enemies and that we will judge other countries, including Communist countries, and specifically countries like Communist China, on the basis of their actions and not on the basis of their domestic ideology" (Nixon, 1967). This shift of U.S. foreign policy focus from the West to the East was in parallel with Washington's wish to be seen as an ordinary nation, not as a superpower in the world affairs. This implied that the Nixon administration 
needed to incorporate new elements in its policy design towards the European Community and European integration process. The United States could no longer enthusiastically support any moves towards European integration. The United States had to act as an ordinary nation. President Nixon had to look after his national interest. In this context, the European Community's leaders desired to build an institutional foundation for their unified positions on world affairs. This collective strength would be useful in protecting the European Community's strategic interests in political discussions with the United States. The Nixon administration's policy to seek détente with the Soviet Union and rapprochement with China was one of the driving forces behind the launch of EPC. Though embracing the birth of EPC, the Nixon administration knew that the European Community was becoming assertive politically and thus Washington had to redefine its approach to the European integration project.

Thi Thuy Hang Nguyen is a doctoral candidate in the School of Global, Urban and Social Studies, the Royal Melbourne Institute of Technology (RMIT University), Australia. She is conducting a research project on U.S. policy towards European integration under the Nixon administration. She received her MA with distinction in International Studies from Sheffield University, United Kingdom in 2011. Her research interests include U.S. foreign policy, U.S.-EU relations, European integration, Asia-Pacific, globalization and Vietnam's politics and foreign policy.

\section{References}

Dinan, D. (2010), Ever Closer Union: An Introduction to European Integration, 4th ed., London: Lynne Rienner.

Dobrynin, A. (1995), In Confidence: Moscow's Ambassador to American's Six Cold War Presidents, Michigan: Times Books.

Dulles, J. F. (1950), War or Peace, London: George G. Harrap \& Co. Ltd.

FRUS (1969-1976a), Memorandum from President Nixon to his Assistant for National Security Affairs (Kissinger), Foreign Relations of the United States, 19691976: China, vol. XVII, Document 3. Retrieved from http://history.state.gov/ historicaldocuments/frus1969-76v17/d3 [accessed 14 Dec 2014]

(1969-1976b), National Intelligence Estimate, Foreign Relations of the United States: Western Europe, NATO, vol. XLI, Document 27. Retrieved from http:// history.state.gov/historicaldocuments/frus1969-76v41/d27\#fn1 [accessed 10 Mar 2015] 
- (1969-1976c), National Security Study Memorandum 14, Foreign Relations of the United States: China, vol. XVII, Document 4. Retrieved from http://history.state. gov/historicaldocuments/frus1969-76v17/d34 [accessed 14 Dec 2014]

— (1969-1976d), Note from the Soviet Leadership to President Nixon, Foreign Relations of the United States: Soviet Union, October 1971 - May 1972, vol. XIV, Document 53. Retrieved from http://history.state.gov/historicaldocuments/ frus1969-76v14/d53 [accessed 10 Dec 2014]

Graebner, N. A; Burns, R. D. \& Siracusa, J. M. (2010), American and the Cold War, 1941-1991: A Realist Interpretation, vol. 2, California: Praeger.

Isaacson, W. (1992), Kissinger: A Biography, New York: Simon and Schuster, Inc.

Kissinger, H. (1974), Transcript of Henry Kissinger's telephone conversation with Stephen Graubard, 18 March 1974, HAK Telcons.

_ (1979), White House Years, Boston: Little Brown \& Co.

Kolodziej, E. A. (1976), 'Foreign Policy \& the Politics of Interdependence: The Nixon Presidency,' Polity, vol. 9, no. 2, pp. 121-157. http://dx.doi. org/10.2307/3234392

NATO (1970), Final Communiqué from the North Atlantic Council Meeting in Rome, 26-27 May 1970. Retrieved from http://www.nato.int/docu/comm/49-95/ c700526a.htm [accessed 13 Feb 2015]

Nixon, R. (1967), 'Asia after Vietnam,' Foreign Affairs, vol. 46, no. 1, pp. 113-125. http://dx.doi.org/10.2307/20039285

(1978), The Memoirs of Richard Nixon, New York: Grosset \& Dunlap.

Paterson, T. G.; Clifford, J. G. \& Hagan, K. J. (1991), American Foreign Policy: A History since 1900, 3rd revised ed., Lexington, MA: D.C. Heath.

Roderick, J. (1971), 'New Page in Relations Opened by American Visit,' The Telegraph, 14 April 1971.

Smith, M. (2012), 'The USA and the EU' in M. Cox \& D. Stokes (eds.) U.S. Foreign Policy, New York: Oxford University Press, pp. 219-238.

Spanier, J. (1980), American Foreign Policy since World War II, California: University of California Press.

The Davignon Report (1970), First Report of the Foreign Ministers to the Heads of State and Government of the Member States of the European Community (The Davignon or Luxembourg Report), Luxembourg, 27 October 1970. Retrieved from http://www.cvce.eu/content/publication/1999/4/22/4176efc3-c734-41e5bb90-d34c4d17bbb5/publishable_en.pdf [accessed 13 Feb 2015]

The Hague Summit Declaration (1969), Communiqué of the Conference of the Heads of State and Government of the Member States of the European Community (The Hague Summit Declaration), The Hague, 2 December 1969. Retrieved from http:// aei.pitt.edu/1451/1/hague_1969.pdf [accessed 12 Feb 2015] 
Thornton, R. C. (2001), The Nixon-Kissinger Years: The Reshaping of American Foreign Policy, 2nd ed., St. Paul, MN: Paragon House.

Williams, P. (1987), 'The Limits of American Power: From Nixon to Reagan,' International Affairs, vol. 63, no. 4, pp.575-587. http://dx.doi.org/10.2307/2619638 